〔農化 第 43 巻, 第 7 号, p. $462 \sim 467,1969$ ]

\title{
高分子電解質の小麦粉生地物理性に対する影響
}

\author{
清 水 徹, 荒木真喜子 \\ （日清製粉中央研究所）
}

昭和 43 年 12 月 24 日受理

\section{Influence of Polyelectrolyte on the Physical Properties of Wheat Flour Dough}

By Toru SHIMIZU and Makiko ARAKI

Central Research Laboratory of Nisshin Flour Milling Co., Ltd.

\begin{abstract}
The influence of gums on the physical properties of wheat flour dough has been studied. From the results of Farinograph absorption, Extensograph structural relaxation and rheological data-elasticity, viscosity, creep and relaxation-, it was observed that the water binding capacity of dough increased remarkably with polyelectrolyte such as sodium alginate.

Alginic acid was found from the gluten fraction separated from the dough containing sodium alginate. From this fact, it is supposed that polyelectrolytes combine with gluten protein strictly.

(Received December 24, 1968)
\end{abstract}

\section{緒言}

タマリンド，ローカストビーン，グアーなどの植物種 子の水溶性多糖類, 寒天, アルギン酸などの海藻の水溶 性多精類，セルロース，澱粉などの水溶性誘導体はガム 類と総称され(1)，食品加工に扣いて增粘㓮や安定剤とし て常用されていることは衆知のとおりである。麦粉を 主原料とする製パン，製菓，製糆などの場合もこれらの ガム類はかなり普遍的に用いられている。

小麦胚乳部にはキシロース、アラビノースより成る水 溶性ペントザンが約 $0.5 \%$ 存在して括り，小麦粉生地の 物理性状に関与していることが知られている.しかしこ のペントザンにはウロン酸は存在していない(2)，そして 稀酸中でグルテン蛋白質とペントザンが相互作用により ゲルを形成することが報ぜられている(8)。

筆者らはカルボキシル基学るつ水溶性多糖類とカルボ キシル基をもたない水溶性多粕類を数種選び，これを小 麦粉に添加した昜合の生地の保水性，レオロジー的性質 について検討を行なった，そして高分子電解質であるア ルギン酸（ポリマンノウロン酸）塩は，グルテン蛋白貿 と結合して増粘効果を示すのであろうという知見を得た ので報告する。

\section{実験材料および実験方法}

1. カ厶類添加小麦粉 小麦粉はカナダ産硬質春小 麦を原料とする Long patent 粉を用いた。乾物べース で灰分 $0.47 \%$ ，粗蛋白 $14.3 \%$ であった。

高分子電解質としてアルギン酸ナトリウム（以下 Alg $\mathrm{Na}$ と略記)，㵶維素グリコール酸ナトリウム(CMC $\mathrm{Na}$ ，解離基の存在しない水溶性多糖類としてタマリン ド種子多糖類 (TamPS)，ローカストビーン種子多糖類 (LBPS) の 4 種をガム類として用いた. これらの市服品 を氷に溶解し，不溶物を除去後，過剩のアルコールを加 えて生じた沈股を集め，含水アルコール，アルコール， エーテルで順次洗浄後乾燥粉碎してガム類試料とした.

小麦粉と所定量のガム類を篩で十分に混合し，ガム類 添加試料粉（以下試料粉と略記）とした。 $1 \%$ 添加とは $100 \mathrm{~g}$ の試料粉の中に $1 \mathrm{~g}$ のが類が含有されているこ とを示すこととする.

2. フォリノグラフによる吸水率の測定試料粉 $300 \mathrm{~g}$ を用い AACC 法の Constant flour procedure ${ }^{(4)}$ により，最大粘稠度が500 単位に達する場合の加水量の 粉に対する比率 $(\%)$ をもって示した。

3. エキステンソグラフによる構造緩和の測定 生 
地はファリノグラフを用い, AACC 法のエキステンソグ ラフ測定法 ${ }^{(5)}$ によって調製した。すなわち試料粉 $300 \mathrm{~g}$, $\mathrm{NaCl} 6 \mathrm{~g}$ に所要の水を加之, 粘稠度 500 単位とした. 同一条件の試料生地 6 個を調製し，初かし時間（温度 $30^{\circ} \mathrm{C}$ ) $10,15,25,40,60,90$ 分として引張り試験 を行ない，伸長度 $5 \mathrm{~cm}$ に拈りる引張り抵抗の経時変化

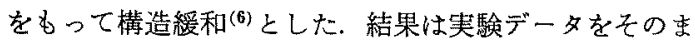
ま示し，奏験式のあてはめは行なわなかった。

4. 二重円筒レオメーターによる粘弾性の測定 等 者らにより生地に適用できるよう考案した Schwedoff の装置(7)を用い，前実験と同一条件で調製した生地（ね2 かし時間 60 分) で $30^{\circ} \mathrm{C}$ におけるクリープおよび回復 奏験を行なった，装置の概要を Fig. 1 に示す。

ねじれ常数 $4.36 \times 10^{4} \mathrm{dyne} \cdot \mathrm{cm}$ のピアノ線で内筒を

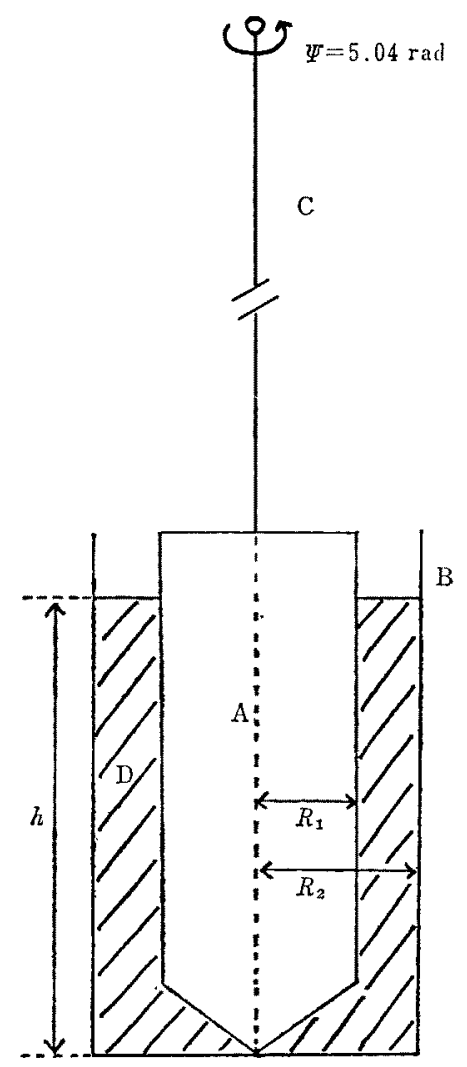

Fig. 1. Double Cone Rheometer (Schwedoff's apparatus).

A : Cylindrical cup $\left(R_{1}=1.50 \mathrm{~cm}\right)$

B : Cylindrical bob $\left(R_{2}=2.50 \mathrm{~cm}\right)$

C : Piano wire $\left(k=4.36 \times 10^{4} \mathrm{dyne} \cdot \mathrm{cm}\right)$

D : Dough $(h=7.6 \mathrm{~cm})$

Temperature of measurement $: 30^{\circ} \mathrm{C}$

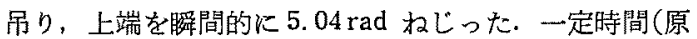
則として 360 秒) 後上端のねじれを解除し回復実験を行 なった.内筒の回転は小鏡を固定し， lamp and scale で則定した

$\begin{array}{ll}\text { 外簡の半径 } & R_{2}=2.50 \mathrm{~cm} \\ \text { 内筒の半径 } & R_{1}=1.50 \mathrm{~cm} \\ \text { 試料生地の長さ } & h=7.6 \mathrm{~cm} \\ \text { ピアノ線ねじれ常数 } & k=4.36 \times 10^{4} \mathrm{dyne} \cdot \mathrm{cm} \\ \text { 上端のねじれ角 } & \psi=5.04 \mathrm{rad} \\ \text { 内筒のねじれ角 } & \Theta \mathrm{rad} \\ \text { 観洞時間 } & t \text { 秒 }\end{array}$

とすると，内筒壁における応力 $p$ 扎よび，ひずみ $e$ は次 のよらになる。

$$
\begin{aligned}
& p=\frac{k \psi}{2 \pi R_{1}{ }^{2} h}=2.16 \times 10^{3} \mathrm{dyne} / \mathrm{cm}^{2} \\
& e=\frac{2 R_{2}{ }^{2} \Theta}{R_{2}{ }^{2}-R_{1}{ }^{2}}=3.125 \Theta
\end{aligned}
$$

したがって，内筒の回転を上端のねじれの $4.5 \%$ 以内， すなわち $\Theta=0.23 \mathrm{rad}, e=0.73$ 以内に抑え, クリープ および回復奏験とみなして以下の解析を行なった。 $e-t$ 関俰加ら常法 ${ }^{(8)}$ に上り Fig. 2 法示四要素模型A に適合せしめついでこれを等価な四要菜模型 B に転換 L, 瞬間弾性率, 逮延弾性率, 遅延時間, 定常粘性率, $2 つ の$ 緩和時間を算出した。

5. アルギン酸の確認 アルギン酸添加生地から分 離した多糖類区分中のアルギン酸の確認は，小麦粉に在 来存在する水溶性へミセルキースにウロン酸の含まれて

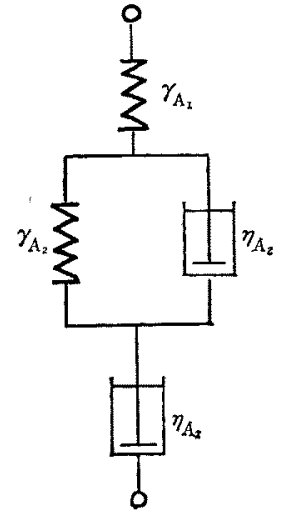

Model A

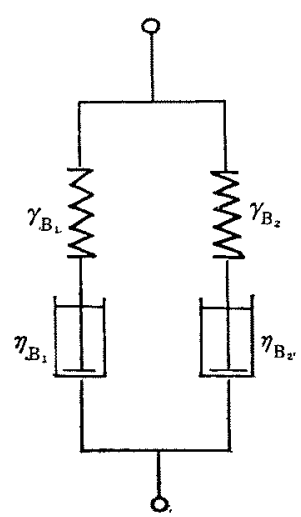

Model B
Fig.2. Four Elements Model.

Retarded time Relaxation time 
いないことから，多糖類区を一定量のアルルリに溶解し， 酸で逆滴定して大略の目安とした.

アルギン酸 $1 \mathrm{mg}=1 / 50 \mathrm{~N} \mathrm{NaOH} 0.250 \mathrm{ml}$

さらに，アルギン酸を塩酸によりフルフラールに分解 し，ついで Bial 試薬と反応せしめて生成する緑青色物 質( ${ }^{(9)}$ の吸収スペクトル上り確認した。

Bial 試蔡：オルシ)ール(3,5-ジヒドロキシトルエ ン $0.714 \mathrm{~g}$ ，硫酸第二鉄アンモニウム $0.06 \mathrm{~g}$ を $75 \mathrm{ml}$ の漶壏酸（此重 1.18）に溶解し，水で $100 \mathrm{ml}$ に定容す る.

万法：アルギン酸 $100 \mu \mathrm{g}$ 程度を含有する水溶液 2 $\mathrm{ml}$ に Bial 試薬 $4 \mathrm{ml}$ を加之, 15 分間沸騰水で加熱後 2 分間冷却し，生成した緑青色物質を $8 \mathrm{ml}$ のアミルア ルコールに転溶し，アミルアルコール層の 600 800 m の吸収スペクトルを求めた。

\section{実験結果および考察}

1. ファリノグラフによる吸水率

Fig. 3 飞 0.5, 1.0\%の AlgNa, CMCNa 涯加粉执よ び $1.0,1.5 \%$ の TamPS, LBPS 添加粉の吸水率を示 †े.

AlgNa とCMCNa, TamPS とLBPS 注きかて類似 した傾向を示し，かつ高分子電解質である前者のグルー プの万が吸水率增加効果の大きいことが認められた。

ファリノグラフは抵抗自記装置をもったミキサーであ

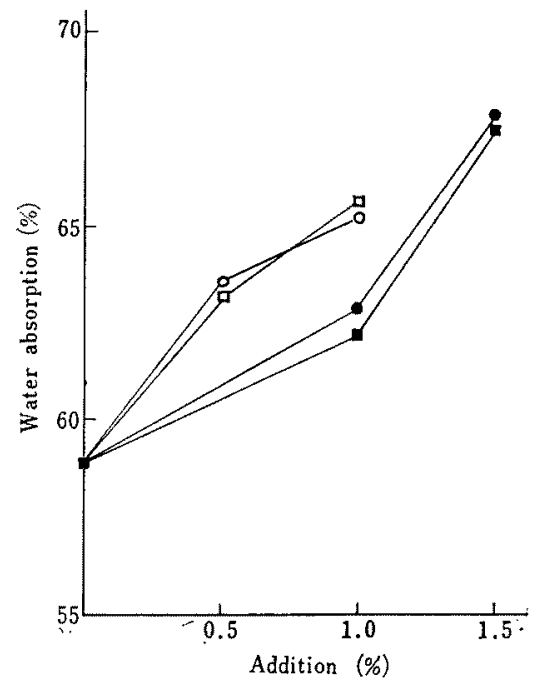

Fig. 3. Farinograph Absorption.

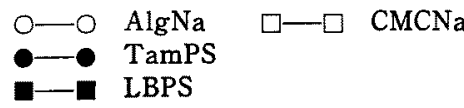

り，粉と水とのミキシング開始後 10 分程度の生地の粘 稠性を尺度として吸办率を推定するるのである。したが

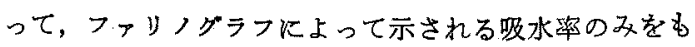
って，生地の一般的な保水性を示すと考えることは危険 である.

\section{2. エキステンソクラフによる構造繯和}

すでに述へたように本実験では $\mathrm{NaCl}$ 添加生地で行な った、フォリノグラフ吸水率を水の場合と食塩水の場合 と比較すると次のと扣りであった。

\begin{tabular}{|c|c|c|c|}
\hline 添加ガム & 添加量 & 吸水率(水) & 吸水 \\
\hline 対 照 & - & $58.5 \%$ & $56.5 \%$ \\
\hline $\mathrm{AlgNa}$ & 0.5 & 63.5 & 60.2 \\
\hline $\mathrm{CMCNa}$ & 0.5 & 63.3 & 60.6 \\
\hline TamPS & 1.1 & 64.0 & 61.6 \\
\hline LBPS & 1.1 & 63.3 & 60.4 \\
\hline
\end{tabular}

$\mathrm{NaCl}$ が共存しても AlgNa， CMCNa の方が TamPS, LBPSょり吸水率增加効果は大きいが，その差は水のみ の場合より小さくなっている。これは高分子電解質の水 溶液の粘性率が塩類によって減少することと共通の現象 と考えられる.

構造綬和の実駼結果を Fig. 4 亿示す.

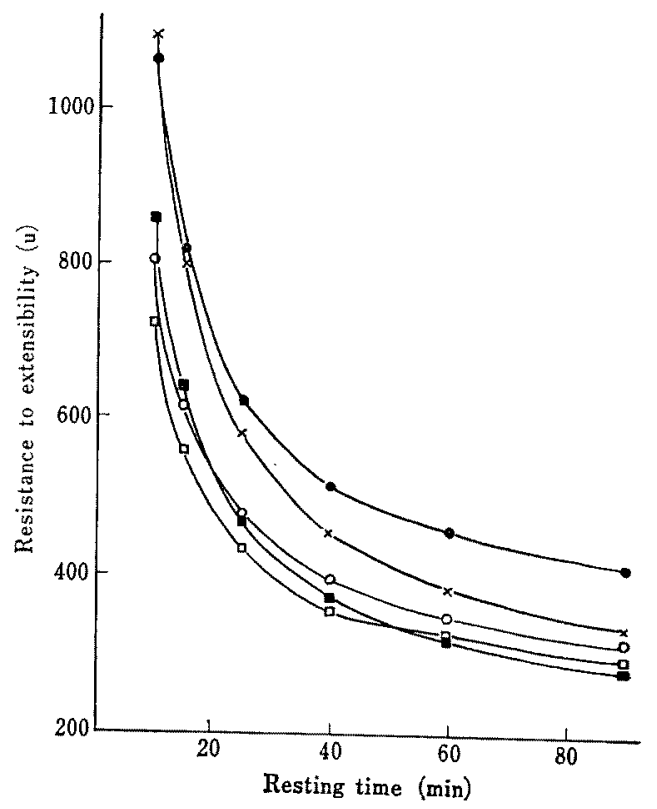

Fig. 4. Extensograph Structural Relaxation.

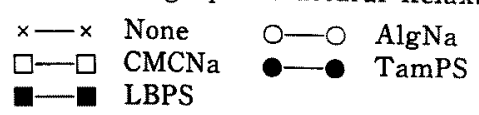


構造緩和は整型により強制的に規則つけられた生地の 内部構造が，经時的に自由な状態に厌万過程を示するの であるが，TamPS 添加生地は対照より和が遅く， AlgNa, CMCNa，LBPS の順に対照より綬和が速いこと が認められたが，五者の間に大きな差がかることは諗め られなかった。

\section{3. レオロジー的性算}

Fig. 5 にクリープおよよび回復実験の結果を示す.

これを基に解析した瞬間弾性率 $\gamma_{A 1}$, 遅延弾性率 $\gamma_{A 2}$, 迤延時間 $\lambda_{A}\left(=\eta_{A 2} / \gamma_{A 2}\right)$, 定常粘性率 $\eta_{A 3} ， 2 \supset 0$ 緩和 時間 $\tau_{B 1}\left(=\eta_{B 1} / \gamma_{B 1}\right), \tau_{B 2}\left(=\eta_{B 2} / \gamma_{B 2}\right)$ を Table I

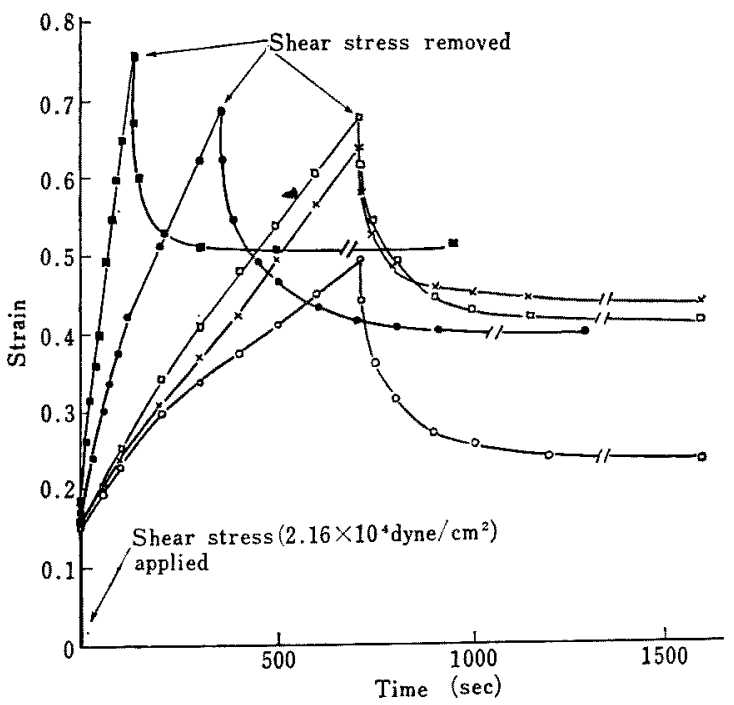

Fig. 5. Creep and Recovery.

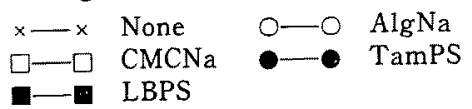

示す。

$A \operatorname{lgNa}$ 派加生地では定常粘性率, 遅延時間拉よび緩 和時間が， $\mathrm{CMCNa}$ 添加生地扎よび TamPS 添加生地 では遅延時間が対照より大きいことが認められた。また LBPS 添加生地では摱間弾性率, 定常粘性率, 遮延時間 および緩和時間が，TamPS 添加生地では定常粘性率战 よび緩和時間が詨照より小さいことが認められた。

以上本節までの三種の実験を総合し，ミキシング中で る生地調整後 1 時間程度でも生地の保水性はガム類の存 在によって向上するが，その度合は $\operatorname{AlgNa}, \mathrm{CMCNa} の$ よらな高分子電解筫が， TamPS, LBPS のような解離基 の無い水溶性多糖類より大きいことが認められた。 そこ

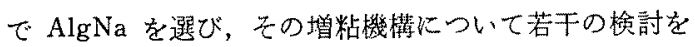
行なった。

\section{4. 小麦粉酸抽出部とアルギン酸の凝結}

ダルテン蛋白質は稀酸によって分散し得ることが知ら れている.小麦粉に 3 倍量の $1 / 50 \mathrm{~N}$ 酢酸を加え, Waring blender で 10 分間室温で㹂汼抽出し， $40,000 \mathrm{~g}$ で遠心 分離した上登をグルテン分散液とした．グルテン分散滩 $100 \mathrm{ml}$ に覺找しながら $0.5 \% \mathrm{AlgNa}$ 水溶液 $30 \mathrm{ml}$ を加

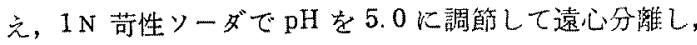
上澄液の窒素を測定した，対照として水尔よびキトザン

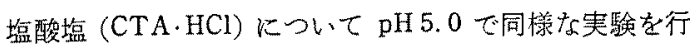
なった，結果は次のとおりである。

\begin{tabular}{|c|c|c|}
\hline & & 上澄液 $\mathrm{N}$ \\
\hline 散夜 & $1+0.5 \% \mathrm{AlgNa} 30 \mathrm{ml}$ & $500 \mu \mathrm{g} / \mathrm{ml}$ \\
\hline " & $+0.5 \% \mathrm{CTA} \cdot \mathrm{HCl} 30 \mathrm{ml}$ & 2100 \\
\hline "1 & $+\mathrm{H}_{2} \mathrm{O} 30 \mathrm{ml}$ & 2300 \\
\hline
\end{tabular}

グルテンの酢酸分散液の $\mathrm{pH}$ を等電点 6.1 の近傍に調 節するとグルテンは㠜結する.これより酸性側の $\mathrm{pH} 5.0$ では水および CTA.HCl 添加区でほ とんど凝結が認められないのに Alg $\mathrm{Na}$ 添加区の場合顕著な凝結が見ら れるのは，この条件下ではグルテン 蛋白質は正に荷電し， $\mathrm{Alg}^{-}$により 電荷を失って沈殿または共沈殿した ものと考えられる。

\section{5. アルギン酸とグルテンの結合}

Fig. 6 に示すごとく，AlgNa 添 加生地 $(\mathrm{NaCl}$ を含まず) から水洗 によりグルテンを採取, 㣀結乾蜗し， 乾燥グルテンを $1 / 50 \mathrm{~N}$ 酢酸に分散, 
酸性プロテアーゼで十分分解した後透析した，透析内液 を微アルカリ性にして遠心分離した不溶物を除き，次に 微酸性に戻して過剩のアルコールを加光，沈皘物を集め て含水アルコールで十分洗浄後, アルコール, エーテル で洗浄乾燥して多糖類区分を得た． $0.3 \% \mathrm{AlgNa}$ 添加粉 生地より得た多糖類区分をPS Alg, 然添加区より得た 多糖類区分をPS None とする，收率は右のとおりであ った.

Flour dough

-Washed with water

Gluten fraction

-Lyophiled

-Dispersed with $1 / 50 \mathrm{~N}$ acetic acid

-Hydrolyzed with acidic protease at $40^{\circ} \mathrm{C}$ for $16 \mathrm{hr}$

-Dialyzed for 5 days

Inner solution

$\leftarrow$ Adjusted $\mathrm{pH} 8.0$

Soluble fraction

$\leftarrow$ Adjusted pH 5.0

$\leftarrow$ Added excess ethanol

-Centrifuged

Precipitation

$\leftarrow$ Washed with $80 \%$ ethanol, ethanol and ether succesively

$\leftarrow$ Dried in vacuo

Polysaccharide fraction

Fig. 6. Separation of Polysaccharide Fraction from Flour Dough.

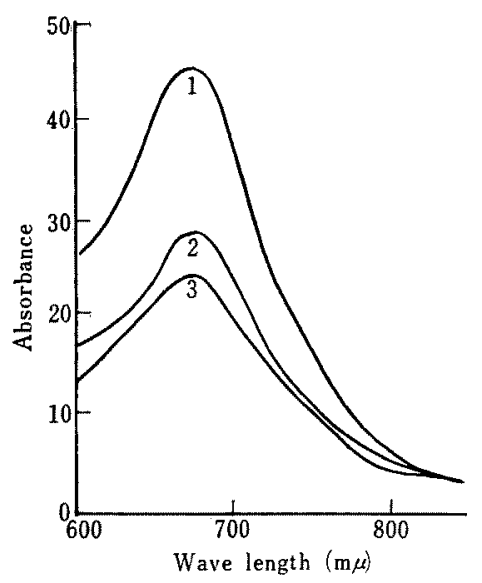

Fig.7. Spectrum of Reactant of Polysaccharide with Bial's Reagent.
1. PS Alg $300 \mu \mathrm{g}$
2. Alginic acid $100 \mu \mathrm{g}$

2. PS None $300 \mu \mathrm{g}$
対グルテン
対小麦粉
PS Alg
$1.68 \%$
$0.202 \%$
PS None
0.28
0.030

PS Alg $300 \mu \mathrm{g} / \mathrm{ml}$, PS None $300 \mu \mathrm{g} / \mathrm{ml}$, Alg 100 $\mu \mathrm{g} / \mathrm{ml}$ の微アルカリ性溶液を作り，Bial 試薬で分解発 色せしぬた吸収スペクトルを Fig. 7 に示す.

図に明らかなごとく，いずれの場台も $670 \mathrm{~m} \mu$ 付近に 吸取の極大が見られたが，Alg の存在が予想でさない PS None でもPS Alg の約 1/2 の吸収が見られた.こ れはフルフラールの生成がアルギン酸のみならずペント 一スでも見られることから当然と考劣られる。

次に PS None とPS Alg t $1 / 10 \mathrm{~N} \mathrm{NaOH}$ に溶解し, $1 / 10 \mathrm{~N} \mathrm{HCl}$ で滴定した.この結果 PS None は注とんど アルカリを消費しないのに対し，PS Alg はアルカリを 消費し, PS Alg 中の酸性物筫をすべて Alg と仮定す ると含量 $33.2 \%$ となった。これより逆算すると粉に添 加した AlgNa の $22.4 \%$ がダルテン区分から回収され たことにたる。

グルテン蛋白質の等電点は pH 6.1 程度であることが 知られている.一方，粉一水生地の $\mathrm{pH}$ は 5.8 前後であ る。したがってグルテン蛋白筫はやや正带電している と考えられる，グルテン蛋白質の正比帯電しらるアミ， 酸残基は 40〜 $50 \mathrm{mM} / 100 \mathrm{~g}$ 蛋白質であることが知られて いる(10).これに対し本実駼の電解質添加量は約 $15 \mathrm{mM} /$ $100 \mathrm{~g}$ 蛋白質である：この条件下で生地から水洗分離し たグルテン区分から $22 \%$ 程度の Alg が回収されたこと は，グルテン蛋白質と高分子電解質の間にかなり強固な イオン的結合が生じ，その結果として生地增粘効果ない しは保水性の向上が見られたものと考えられる。

\section{要 旨}

（1）ガム類添加生地の物理性状をファリノグラフ吸 水率, エキステンソグラフ構造緩和，二重円筒レオメー ターによる粘弾性により測定し、アルギン酸, 縅維素グ リコール酸のナトリウム塩のよらな高分子電解質は，女 マリンド， ローカストビーン種子多糖類などの解離基の ない水溶性多糖類より增粘効果が大きいことを認めた。

（2）アルギン酸添加生地から分離したグルテン区分 にアルギン酸の存在を認めた，高分子電解質の生地増粘 作用はグルテン蛋白質とのかなり強固な結合によって生 ずると考克られる.

終りに䧢み, 本研究の実施に御指導いただいた日清製 
粉中央研究所長室橋正男氏，本研究の発表を許可された 同社幹部の力々に厚く御礼申し上げます。

(1) R.L. Whistler ed: Industrial gums, Academic Press 1959.

(2) I. Hlynka ed : Wheat, Chemistry and Technology, AACC, 1964, p. 312.

(3) D.C. Udy : Cereal Chem. 34, 37 (1957).

(4) Cereal Laboratory Methods, 54-21, AACC (1963).

(5) ibid., 54-10, AACC (1963).
(6) I. Hlynka : The Bakers Digest, 29, 27 (1955).

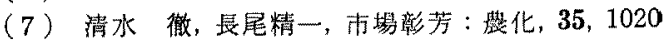
(1961).

（8）中川猚太郎，神戸博太郎：レホロジー，みすす

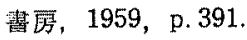

(9) E.G.Brown and T.J.Hayes: The Analyst, 77, 445 (1952).

(10) B. Sullivan : Cereal Sci. Today, 10, 338 (1965). 